\title{
Long-term monitoring reveals topographical features and vegetation that explain winter habitat use of an Arctic rodent
}

\author{
Xaver von Beckerath, Gita Benadi, Olivier Gilg, Benoît Sittler, Glenn Yannic, \\ Alexandra-Maria Klein, and Bernhard Eitzinger
}

\begin{abstract}
The quality of wintering habitats, such as depth of snow cover, plays a key role in sustaining population dynamics of Arctic lemmings. However, few studies so far investigated habitat use during the Arctic winter. Here, we used a unique long-term time series to test whether lemmings are associated with topographical and vegetational habitat features for their wintering sites. We examined yearly numbers and distribution of 22769 winter nests of the collared lemming Dicrostonyx groenlandicus (Traill, 1823) from an ongoing long-term research on Traill Island, Northeast Greenland, collected between 1989 and 2019, and correlated this information with data on dominant vegetation types, elevation, and slope. We found that the number of lemming nests was highest in areas with a high proportion of Dryas heath, but was also correlated with other vegetation types, suggesting some flexibility in resource use of wintering lemmings. Furthermore, lemmings showed a higher use for sloped terrain, probably as it enhances the formation of deep snow drifts, which increases the insulative characteristics of the snowpack and protection from predators. With global warming, prime lemming winter habitats may become scarce through alteration of snow physical properties, potentially resulting in negative consequence for the whole community of terrestrial vertebrates.
\end{abstract}

Key words: Arctic tundra, climate change, Dicrostonyx groenlandicus, habitat use, population dynamics.

Résumé : La qualité des habitats d'hivernage, comme l'épaisseur de la couverture de neige, joue un rôle clé dans le maintien de la dynamique des populations de lemmings arctiques. Cependant, peu d'études ont été menées jusqu'à présent sur l'utilisation de l'habitat pendant l'hiver arctique. Les auteurs ont utilisé ici une série chronologique à long terme unique pour vérifier si les lemmings sont associés à des caractéristiques topographiques et végétales de leurs sites d'hivernage. Ils ont examiné le nombre annuel et la distribution de 22769 nids d'hiver du lemming à collier Dicrostonyx groenlandicus (Traill, 1823) dans le cadre d'une recherche à long terme en cours sur l'île de Traill, au nord-est du Groenland, recueillis entre 1989 et 2019, et corrélé ces informations avec des données sur les types dominants de végétation, l'altitude et la pente. Ils ont constaté que le nombre de nids de lemmings était le plus élevé dans les zones présentant une forte proportion de bruyère Dryas, mais qu'il était

\footnotetext{
Received 9 February 2021. Accepted 7 July 2021.
}

X. von Beckerath, B. Sittler, A.-M. Klein, and B. Eitzinger. Chair of Nature Conservation and Landscape Ecology, University of Freiburg, Freiburg im Breisgau, Baden-Württemberg, Germany.

G. Benadi. Biometry \& Environmental System Analysis, University of Freiburg, Freiburg im Breisgau, BadenWürttemberg, Germany.

O. Gilg. UMR 6249 Chrono-environnement, Université de Bourgogne Franche-Comté, Besancon, Bourgogne, France.

G. Yannic. Université Grenoble Alpes, Université Savoie Mont Blanc, CNRS, LECA, 38000 Grenoble, France.

Corresponding author: Xaver von Beckerath (email: xaver.vonbeckerath@posteo.net).

(C) 2021 The Author(s). This work is licensed under a Creative Commons Attribution 4.0 International License (CC BY 4.0), which permits unrestricted use, distribution, and reproduction in any medium, provided the original author(s) and source are credited. 
également corrélé avec d'autres types de végétation, ce qui suggère une certaine flexibilité dans l'utilisation des ressources par les lemmings hivernants. En outre, les lemmings montraient une plus grande utilisation des terrains en pente, probablement parce qu'ils favorisent la formation de congères profondes qui accroissent les caractéristiques isolantes du manteau neigeux et la protection contre les prédateurs. Avec le réchauffement climatique, les principaux habitats hivernaux des lemmings pourraient se raréfier en raison de la modification des propriétés physiques de la neige, ce qui pourrait avoir des conséquences négatives pour l'ensemble de la communauté des vertébrés terrestres. [Traduit par la Rédaction]

Mots-clés : toundra arctique, changement climatique, Dicrostonyx groenlandicus, utilisation de l'habitat, dynamique des populations.

\section{Introduction}

Climate change is impacting the Earth's ecological and biological systems. According to the Intergovernmental Panel on Climate Change, the Arctic surface temperature has increased twice as fast as the global average over the last 20 years, with alterations in precipitation, snow cover, and permafrost temperature (Pörtner et al. 2019). Environmental change has triggered measurable shifts in performance and distributions of plant and animal species, translating into ecosystem-wide changes (Post et al. 2009). Among vertebrates, lemmings play a key role in the High Arctic tundra food web (Batzli et al.1980). They are year-round residents and thus have to survive on local primary production throughout the year (Soininen et al. 2015). As a key prey for many terrestrial Arctic predators, lemmings impact reproduction and abundance of those, which in turn creates feedbacks on lemming cyclic dynamics (Sittler et al. 2000; Gilg et al. 2003, 2006; Therrien et al. 2014). Lemmings are well known for their regular, large-amplitude population cycles (Ims and Fuglei 2005), with population peaks every 3-5 years (Gilg et al. 2003; Gruyer et al. 2008; Ehrich et al. 2020). Although predator-prey interactions are commonly argued to be the cause of the lemming cycles (Gilg et al. 2003; Fauteux et al. 2016), the role of the environment in the modulation of such dynamics is only poorly understood (Kausrud et al. 2008).

Collapsing lemming cycles have been observed at different sites in the Arctic, including Northeast Greenland (Kausrud et al. 2008; Gilg et al. 2009; Schmidt et al. 2012b; Ehrich et al. 2020). The most prevailing explanation for these disruptions is the impact of changing snow characteristics due to climate change (Ims et al. 2008; Kausrud et al. 2008; Gilg et al. 2009). Thick snow cover insulates wintering lemmings from low ambient air temperatures and increases their protection from predators (Reid et al. 2012). Thus, a thin snowpack appears to be a strong limiting factor for recruitment and lemming survival, which may maintain lemming populations at low densities (Reid and Krebs 1996; Bilodeau et al. 2013b; Domine et al. 2018).

The collared lemming Dicrostonyx groenlandicus (Traill, 1823) is found in High Arctic ecosystems of northern Canada, Alaska, and Greenland. Dry dwarf-shrub heath and herb slopes, which are rich in Salix arctica Pall. and Dryas spp. L., are the preferred summer habitats of the collared lemming (Batzli et al. 1983; Predavec and Krebs 2000; Schmidt 2000; Ale et al. 2011; Morris et al. 2011). However, habitat use during winter remains poorly known due to the challenges involved in studying them beneath the snow in the harsh winter Arctic conditions (Soininen et al. 2015). Yet, successful reproduction during the winter season plays a key role in lemming population dynamics (Ims et al. 2011; Bilodeau et al. 2013) and it is even considered a necessary condition for the occurrence of a population outbreak (Fauteux et al. 2015). Lemmings build subnivean nests (i.e., nests under the snow) made of vegetation, which are assumed to provide insulation against low 
temperatures and to protect litters from predation (Sittler 1995; Duchesne et al. 2011; Domine et al. 2018).

Winter nests are generally built on the ground or within the snowpack. After snowmelt, these nests can be found on the ground with no signs of connection to the vegetation below. Collared lemmings stay in their winter quarters until the snowpack is soaked with melt water and collapses. By that time, lemmings seek their summer habitats in dry and early snow free heath lands (Fauteux et al. 2018). So far, surprisingly few studies have investigated these nests to identify habitat usage during winter, even though winter nests can be easily spotted after snowmelt in the Arctic tundra.

To date, the most comprehensive study exploring the effects of snow cover and habitat features on the distributions and reproduction of winter nests took place on Bylot Island, Canada (Duchesne et al. 2011). Here, collared lemming nests, sampled over two consecutive years, were mainly located in areas with high microtopography heterogeneity, steep slopes, deep snow, and a high cover of mosses (Duchesne et al. 2011). Other studies focused solely on the relationship between snow cover and winter nests. These studies noted a concentration of winter nests in areas of greatest winter snow accumulation (Reid and Krebs 1996; Reid et al. 2012; Bilodeau et al. 2013), in particular on sloped terrain, which provides shelter for the deposition of wind-blown snow in drifts (Reid et al. 2012). The geographically closest study in Zackenberg identified Salix snow bed as the vegetation with the highest winter nest densities, most likely due to its favorable microclimate caused by high microtopographic variability and deep snow (Schmidt et al. 2021).

Thick snow cover has been identified as one of the main drivers for lemming nesting sites; however, for vegetation, no clear pattern has been detected that would explain how they choose their winter habitat. This could be due to the fact that most studies so far exclusively captured individual population phases (Duchesne et al. 2011; Reid et al. 2012; Soininen et al. 2015), possibly ignoring the effect of a cycling population on habitat use, i.e., a potential density-dependent effect (but see Schmidt et al. 2021). The assumption is that lemmings undergo density-dependent dispersal as a result of intraspecific competition in the subnivean space and may be forced to emigrate to less optimal habitats, as preferred sites are thought to be limited (Morris et al. 2000). Collared lemming habitat selection was for example density-dependent in Zackenberg (Schmidt et al. 2021), thus making an investigation necessary. This study is unique in terms of examining the long-term determinants of winter habitat use of lemmings by analyzing data collected over 30 years. Using this rare time series, we were able to define characteristics of lemming winter habitats at an unprecedented temporal scale. The objective of our study is to determine the ecological factors influencing the spatial distribution of winter nests of collared lemmings, allowing to identify areas of frequent habitat use at a landscape scale. Habitat use is defined as the way an animal consumes a collection of physical and biological components in a habitat, while habitat selection takes into account the availability of resources (Hall et al.1997), which we were not able to consider in our analysis. We hypothesize that lemmings mainly use areas providing a deep snow cover and a rich plant food source. As Dryas heath hosts the highest abundance of preferred food plants (Rodgers and Lewis 1985; Bergman and Krebs 1993; Berg 2003), we predict that (1) sites with a greater abundance of Dryas heath and greater vegetation cover have a positive effect on nest counts. Furthermore, because snow depth is highest at the bottom of steep slopes, we predict that (2) the number of lemming winter nests is higher on sites with increased slopes. 


\section{Materials and methods}

Study area

This study was carried out as part of the joint French-German research project "Karupelv Valley Project" (https://www.karupelv-valley-project.de/english; http:// www.grearctique.org/karupelv). The core research area covers approximately $15 \mathrm{~km}^{2}$ and is located on the southwestern coast of Traill Island, Northeast Greenland $\left(72.5^{\circ} \mathrm{N}, 24^{\circ} \mathrm{W}\right.$; Fig. 1). The study area is bordered by the Karupelv River to the south and the Eskdal River to the east (Fig. 1). The northern border follows small streams and geomorphological structures towards the coast (Rau 1995). The region is part of the Northeast Greenland National Park and offers a study site with minimal human impact for long-term surveys (Sittler 1995). The closest weather station (Zackenberg, approximately $250 \mathrm{~km}$ north) measures mean summer temperatures of $5.8^{\circ} \mathrm{C}$ in July and mean winter temperatures of $-22.4{ }^{\circ} \mathrm{C}$ in February. Annual precipitation is $261 \mathrm{~mm}$ with relatively dry summers as most falls as snow in winter (Hansen et al. 2008). Snow cover is usually present from September to June or July (Gilg et al. 2009). The study area covers lowlands and sloped terrain of different scales, the maximum slope gradient is $67^{\circ}$ and the area spans elevation ranges from 0 to $122 \mathrm{~m}$ a.s.l. (Porter et al. 2018). The site is classified as High Arctic tundra (Walker et al. 2005) and has six dominating vegetation types (Rau 1995) (Table 1). The dominant mammal species is the collared lemming, which forms the main prey for Arctic fox Vulpes lagopus (Linnaeus, 1758), stoat Mustela erminea Linnaeus, 1758, snowy owl Bubo scandiacus (Linnaeus, 1758), and, during peak years, also for Long-tailed Jaeger Stercorarius longicaudus Vieillot, 1819 (Gilg et al. 2006; Andreassen et al. 2017).

\section{Winter nest survey}

Although several lemmings can inhabit the same nest (Rodgers and Lewis 1986), winter nests are a good proxy of lemming population densities (Gilg et al. 2006). Winter nests were recorded by the same person (B.S.) from 1988 to 2019. The census took place between the end of June and the beginning of August, i.e., for about 4 weeks after snowmelt. Because nests need to be destroyed upon recording to avoid double counting in the following years, the first year of data assessment was omitted. Hence, this study includes 31 years of data (1989-2019). To perform an exhaustive recording of all nests, systematic transects were walked on a yearly basis across the whole area. Their width is dictated by the detectability of the nests: These transects cover a band of $30 \mathrm{~m}$ width in flat areas and $20 \mathrm{~m}$ width in rugged terrain. High quality aerial photography was used to divide the study region into grid cells and ensure that the same census effort was devoted to each cell (Sittler 1995). The same aerial photography was then cut into portable sheets to assign nest records to specific $250 \mathrm{~m} \times 250 \mathrm{~m}$ cells in the field. This methodology gives indices on relative abundance, habitat use, and spacing patterns during winter (Sittler 1995).

\section{Data processing}

Answering our research questions required the creation of a digital version of the abovementioned grid. GIS-based data management and extraction was implemented with ArcMap 10.7.1. First, all aerial photograph sheets were georeferenced with a high-resolution $(10 \mathrm{~m})$ satellite image (Supplementary Fig. S1 ${ }^{1}$ ) from the Copernicus Mission (Copernicus Sentinel data 2017). Next, a new digital grid was created that matched the analogue one in a best-fit scenario. As the aerial photographs did not align perfectly, some deviation was expected (Supplementary Fig. S10 ${ }^{1}$ ). Many of the contiguous aerial photographs slightly overlapped with each other (Supplementary Figs. S2 and S3 ${ }^{1}$ ), thus it was necessary to

\footnotetext{
${ }^{1}$ Supplementary data are available with the article at https://doi.org/10.1139/as-2021-0010.
} 
Fig. 1. Cumulated number of lemming winter nests censused between 1989 and 2019 on 274 grids of ca. $250 \mathrm{~m} \times 250 \mathrm{~m}$ in the Karupelv Valley on Traill Island, Northeast Greenland. Software used to create this map: ArcMap 10.7.1. Contour lines created with topographic data from the ArcticDem project (Porter et al. 2018). Coastal data extracted from Natural Earth (Patterson and Vaughn Kelso 2018). Rivers were drawn with satellite imagery from the Sentinel project (Copernicus Sentinel data 2017). Coordinate system: WGS 1984 UTM Zone 26N. Projection: Transverse Mercator.

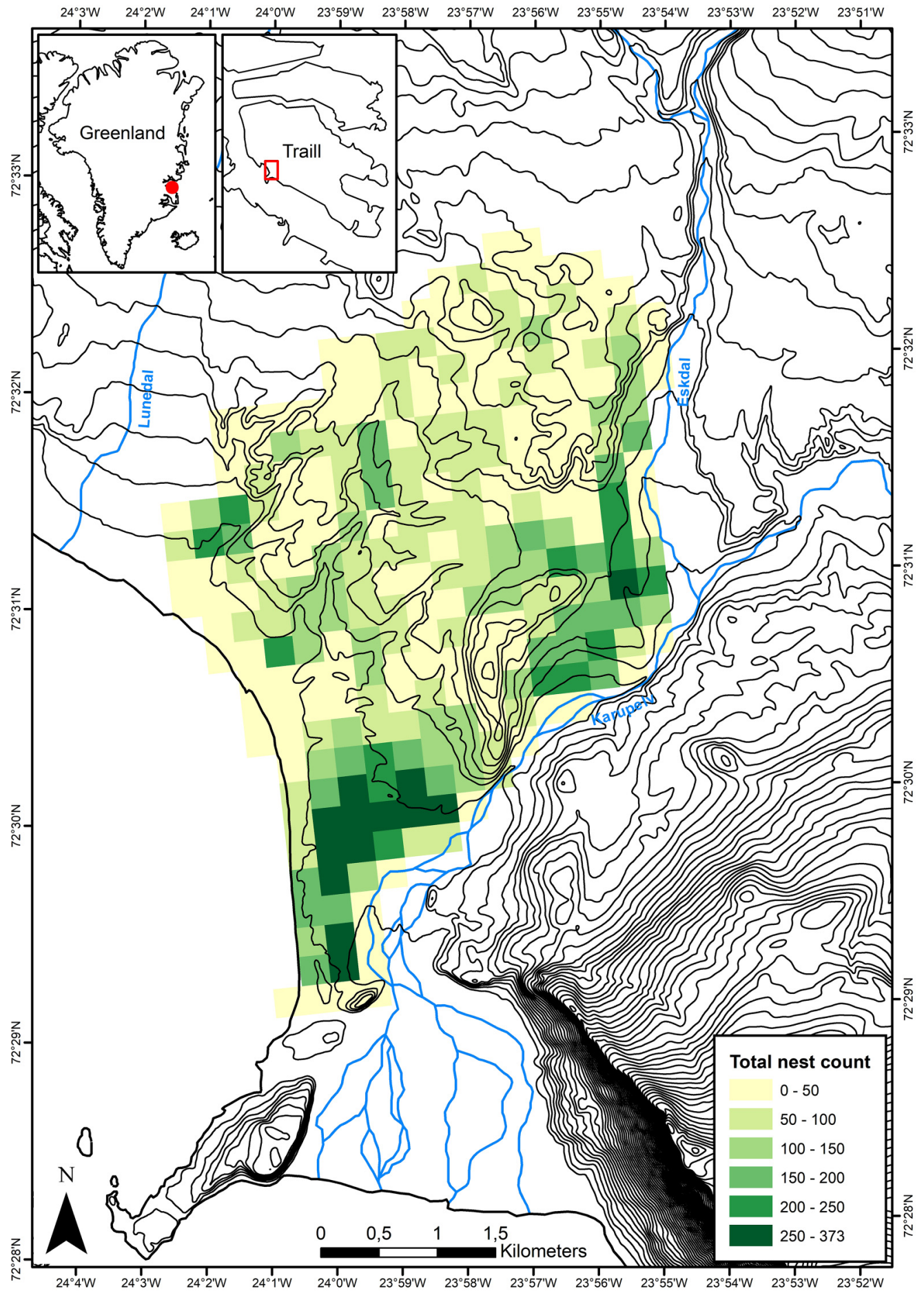

- Published by Canadian Science Publishing 
Table 1. Dominant six vegetation types of the Karupelv Valley with a short description and unit (see Rau 1995).

\begin{tabular}{|c|c|c|}
\hline Variable & Description & Unit \\
\hline Cassiope heath & Pure stands of Cassiope tetragona (L.) D. Don. & Up to $62500 \mathrm{~m}^{2}$ per cell \\
\hline Dryas heath & Dominated by $D$. octopetala $\times$ integrifolia & Up to $62500 \mathrm{~m}^{2}$ per cell \\
\hline Spot tundra & $\begin{array}{l}\text { Sparse vegetation with sporadically occurring vegetation } \\
\text { islands of Cassiope heath and Dryas heath }\end{array}$ & Up to $62500 \mathrm{~m}^{2}$ per cell \\
\hline Moss-sedges tundra & $\begin{array}{l}\text { Wet vegetation dominated by mosses and relatively tall } \\
\text { sedges (Carex spp. L., Eriophorum scheuchzeri Hoppe) }\end{array}$ & Up to $62500 \mathrm{~m}^{2}$ per cell \\
\hline Floodplain vegetation & $\begin{array}{l}\text { Species- and individual-poor recent floodplains with } \\
\text { various species of rockfoils (e.g., Saxifraga aizoides L.) }\end{array}$ & Up to $62500 \mathrm{~m}^{2}$ per cell \\
\hline Sand dunes & Vegetation-free areas characterized by sand dunes & Up to $62500 \mathrm{~m}^{2}$ per cell \\
\hline
\end{tabular}

manually merge certain cells and create a new grid identification system (Supplementary Fig. $4^{1}$ ). Nest counts were translated to the new identification system and assigned to the digital grid. Single cells, which were located outside the core study area and did not contain any nest recordings, were erased. Therefore, the new grid consists of 274 cells of $250 \mathrm{~m} \times 250 \mathrm{~m}\left(62500 \mathrm{~m}^{2}\right)$ in size, with a total extent of approximately $15 \mathrm{~km}^{2}$.

Elevation ( $\mathrm{m}$ a.s.1.) and slope (degrees) were extracted from a digital elevation model ( $5 \mathrm{~m}$ resolution) supplied by the ArcticDem project (Porter et al. 2018). Elevation and slope were calculated for each cell by taking the mean of all raster cells in that patch (Supplementary Fig. S5 ${ }^{1}$ ). Vegetation data was derived from a geo-ecological study of the study region (Rau 1995). This study analyzed vegetation types at the end of the growing season in early August. It classified 13 different vegetation types throughout the core research area (Supplementary Table S3 ${ }^{1}$ ). Given the slow changes in vegetation in the region (Schmidt et al. 2012a), we considered that this data set was relevant to use for the entire study period. Additional detailed information on the study area and the underlying data with corresponding figures can be found in the Supplementary material (Supplementary Figs. S1-S15 ${ }^{1}$ and Supplementary Tables $\mathrm{S} 1-\mathrm{S} 5^{1}$ ).

\section{Statistical analysis}

In the model, the number of lemming winter nests per grid cell is the response variable and mean elevation per cell, mean slope per cell, and the area of each vegetation type in the cell are explanatory variables. All variables are continuous. Although we also calculated a measure of terrain ruggedness, this model failed to converge. We suspect that the limited amount of information in the data did not allow estimating such a high number of parameters. Due to the large number of different vegetation types, only the six dominant (spot tundra, moss-sedges tundra, Dryas heath, Cassiope heath, and sand dunes) were included in this study (Supplementary Table S $3^{1}$ ). All predictors were standardized to a mean value of 0 and a standard deviation of 1 , to facilitate model convergence and enable us to compare the explanatory contributions of each independent variable regardless of units. Testing all predictors for correlation produced correlation coefficients smaller than 0.41 . Additionally, we performed a variance inflation factor test (Zuur et al. 2010), which showed that none of the eight input variables has collinearity problems. Due to the high interannual fluctuations in winter nest numbers, the proportion of empty cells varied greatly between years (Supplementary Table S4${ }^{1}$ ). We first fitted a generalized linear model with a Poisson distribution and log link function to the data, but because diagnostic tests indicated significant overdispersion and zero inflation, we used a zero-inflated negative binomial generalized linear model as our final model, with only an intercept fitted to account for the excess number of zeros. Additionally, we accounted for possible non-independence 
Table 2. Summary table of negative binomial generalized linear model of the effect of vegetation type, elevation, and slope on total lemming nest number for all years (1989-2019).

\begin{tabular}{lclrr}
\hline Fixed factors & Estimate & Std. error & $Z$ value & $P$ value \\
\hline Intercept & -0.39752 & 0.22342 & -1.779 & 0.0752 \\
Spot tundra & $\mathbf{0 . 3 8 8 3 8}$ & $\mathbf{0 . 0 7 6 0 8}$ & $\mathbf{5 . 1 0 5}$ & $<\mathbf{0 . 0 0 1}$ \\
Moss-sedges tundra & $\mathbf{0 . 3 6 9 0 3}$ & $\mathbf{0 . 0 6 9 7 5}$ & $\mathbf{5 . 2 9 1}$ & $<\mathbf{0 . 0 0 1}$ \\
Dryas heath & $\mathbf{0 . 7 6 3 3 1}$ & $\mathbf{0 . 0 8 5 0 7}$ & $\mathbf{8 . 9 7 2}$ & $<\mathbf{0 . 0 0 1}$ \\
Cassiope heath & 0.06993 & 0.06196 & 1.129 & 0.2591 \\
Sand dunes & -0.03833 & 0.06954 & -0.551 & 0.5815 \\
Floodplain vegetation & $-\mathbf{0 . 1 5 1 4 9}$ & $\mathbf{0 . 0 6 8 5 3}$ & $\mathbf{- 2 . 2 1 1}$ & $\mathbf{0 . 0 2 7 1}$ \\
Mean slope & $\mathbf{0 . 2 6 9 6 4}$ & $\mathbf{0 . 0 6 7 5 5}$ & $\mathbf{3 . 9 9 2}$ & $<\mathbf{0 . 0 0 1}$ \\
Mean elevation & $-\mathbf{0 . 3 3 5 7 8}$ & $\mathbf{0 . 0 8 0 8 4}$ & $\mathbf{- 4 . 1 5 4}$ & $<\mathbf{0 . 0 0 1}$ \\
\hline
\end{tabular}

Note: Significant results are in boldface type.

of data points by testing for spatial autocorrelation of model residuals separately for each year and for temporal autocorrelation separately for each grid cell. Because spatial autocorrelation was detected in 23 of 31 years and temporal autocorrelation in 20 of 274 grid cells (Supplementary Table $S 5^{1}$ ), we subsequently applied a Matérn covariance structure to account for spatial autocorrelation and an autoregression structure (AR1) to account for temporal autocorrelation. To test for density effects on habitat use, we opted to include yearly nest densities as a continuous variable in the model. However, due to convergence issues, we then alternatively calculated separate models for years with low ( $<2$ lemmings) ha) and high ( $>2$ lemmings/ha) winter nest densities (Gilg et al. 2019).

Simulation-based standardized residuals were used to check for patterns in the residuals against fitted values and predictors. All statistical analyses were performed with $R$ 4.0 ( $\mathrm{R}$ Core Team 2020) and the packages glmmTMB (Brooks et al. 2017) and DHARMa (Hartig 2017).

\section{Ethics approval}

All surveys were approved under the Ministry for Nature, Environment and Justice of the Government of Greenland (1988-2019). Permission to conduct research in the Northeast Greenland National Park in 2019 was given under the license no. C19-36.

\section{Results}

In total, 22769 individual fresh nests were counted on 274 grid cells during 31 years. Seven of these cells (2.6\%) did not host any nests at any time, while the highest cumulative number recorded in one cell reached 373 nests. We found only minimal differences of habitat use between years of low and high lemming density. The results of both models show the same significant factors and similar numbers in all the estimates (Supplementary Tables S1 and S2 ${ }^{1}$ ). Therefore, we here present the results of the model including all years, despite the large difference in total lemming density (Table 2). Six of eight factors in our model were significantly correlated with lemming nest numbers (Fig. 3). However, the uncertainty around estimated effects was generally large (Fig. 2). More nests were found when the cover of these three habitat types increased: spot tundra (Fig. 2a), moss-sedges tundra (Fig. 2b), and Dryas heath (Fig. 2c). Conversely, the number of lemming nests declined with an increase in floodplain vegetation (Fig. $2 d$ ), while we found no effect for Cassiope heath and sand dunes. Regarding geophysical variables, the number of nests increased with increasing slope (mean \pm SE: $4.21 \% \pm 0.161 \%$ ) (Fig. $2 e$ ) while elevation (mean for all grids: $50 \mathrm{~m}$; range: 0-119 $\mathrm{m}$; $\mathrm{N}$ : 274) had a negative effect (Fig. 2f), meaning that fewer nests were found at high elevation. 
Fig. 2. (a-f) Effect plots for all significant predictors (standardized) comparing winter nest densities of collared lemmings in a High Arctic tundra at Karupelv Valley across all years (1989-2019). Nest counts are shown per grid. Shaded area represents $95 \%$ confidence intervals. Software used to create this figure: $\mathrm{R}$ 4.0.1.

(a)

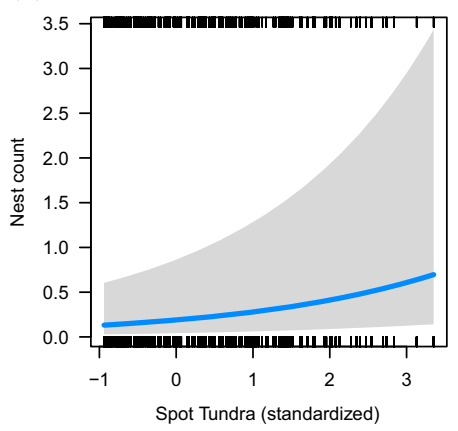

(d)

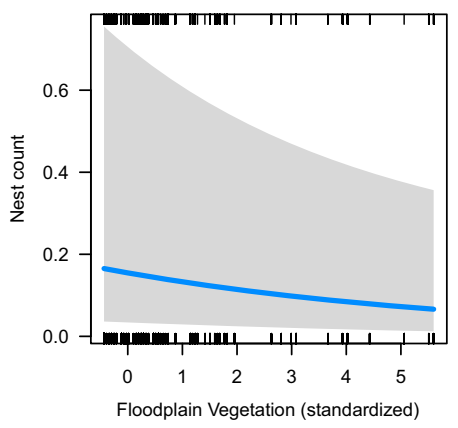

(b)

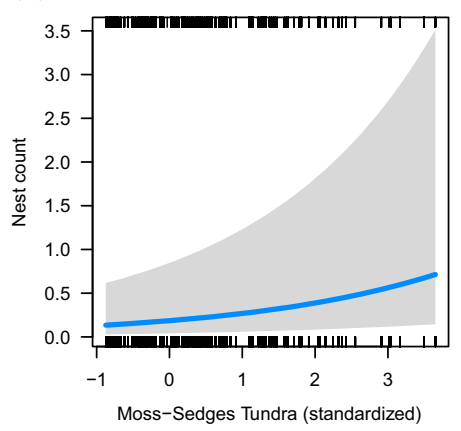

(e)

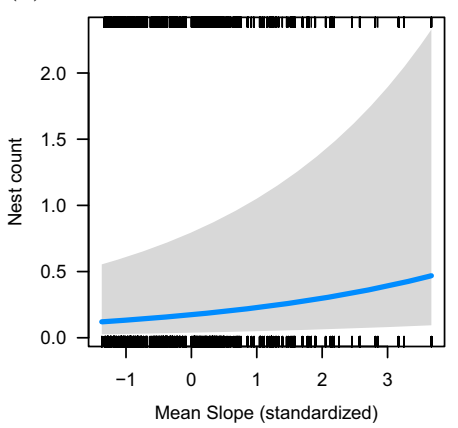

(c)

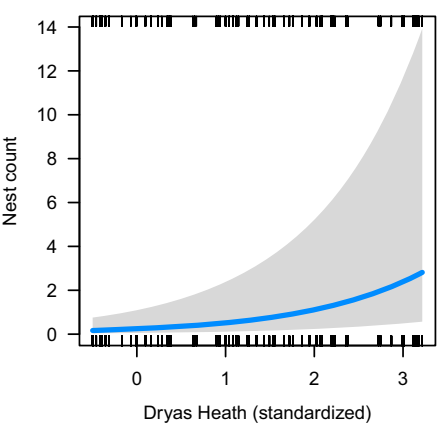

(f)

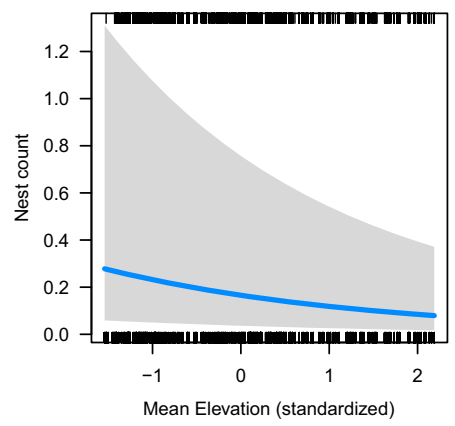

Fig. 3. Forest plot for all predictors (standardized) comparing winter nest densities of collared lemmings in a High Arctic tundra at Karupelv Valley across all years (1989-2019). ${ }^{*}, P<0.05$; ***, $P<0.001$. Software used to create this figure: R 4.0.1.

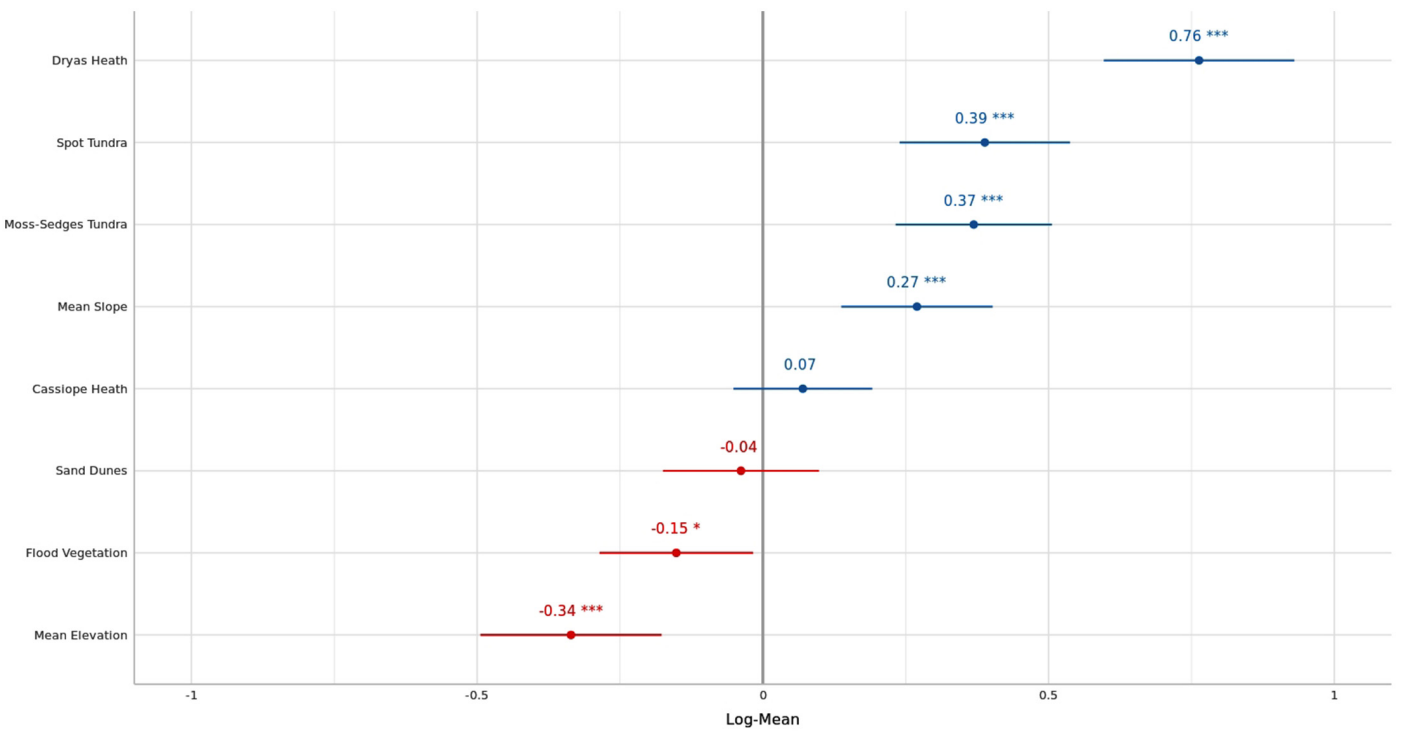

Published by Canadian Science Publishing 


\section{Discussion}

This study is unique as it examines the long-term determinants of winter habitat use of lemmings on landscape-scale covering a whole valley by analyzing data collected over 30 years. Corroborating results from recent short-term studies (Duchesne et al. 2011; Reid et al. 2012), we found that both (1) sites with a greater cover of Dryas heath and greater vegetation cover have a positive effect on nest counts, and (2) the number of lemming winter nests is higher on sites with increased slopes. In addition, we found no evidence for shifts in habitat use between years of high and low population size, suggesting that lemmings are not constrained by habitat resources. However, the nature of our data (e.g., relatively coarse spatial scale) may mask such interannual variation in habitat use. Below, we will examine each finding in turn.

Our study shows that collared lemmings are not restricted to one vegetation type during the winter months, but instead use multiple vegetation types. Winter nests were more abundant at locations with a greater proportion of Dryas heath than in places that were dominated by spot tundra or moss-sedges tundra, which all host a different plant species composition (Supplementary Table S3 ${ }^{1}$ ). We can thus accept the first hypothesis that lemming cluster at sites with Dryas heath and key food plant species (e.g., S. arctica, Dryas octopetala $\times$ integrifolia) therein. In Traill island, Dryas heath is widespread (encompassing $14.45 \%$ of the study area) and as it represents a hybridization zone of $D$. octopetala and D. integrifolia. Consequently, it can be found in windswept ridges as well as areas of late-lying snow (Viereck and Little 2007). Our results fit into a series of studies across the Arctic that document a preference of Dryas but also some flexibility in the use of habitats by lemmings, as main nests sites vary depending on the dominance of different plant species: Dryas was preferred by lemmings at Igloolik (Nunavut, Canada), based on live-trapping in the snowpack (Rodgers and Lewis 1985). By contrast, in regions with low abundance of Dryas, Salix was found to be dominant habitat type as indicated by the location of nests, associated latrine sites, and faecal pellets in Northern Greenland (Klein and Bay 1994; Schmidt et al. 2021) and percentage of shoots clipped after snowmelt in Alaska, respectively (Batzli et al. 1983).

In our study, Cassiope heath cover did not affect winter site use by lemmings. This is in line with the more recent study in Zackenberg, where Cassiope heath was the least favored vegetation type (Schmidt et al. 2021). In fact, lemmings were only observed to eat the flowers of Cassiope, which are available during summer (Berg 2003). Conversely, we expected Cassiope heath to be attractive for lemmings as an indicator for snowbeds (Pedersen et al. 2016). However, as Cassiope only covers $4 \%$ of the total area, we were unable to detect positive or negative effects on lemming densities.

The most comparable study so far listed areas with a low abundance of lichens and a high abundance of mosses as preferred sites for winter nests (Duchesne et al. 2011). Collared lemmings have also been found to consume a greater proportion of mosses during the winter than during the summer (Rodgers and Lewis 1986), possibly because mosses contain fatty acids keeping body temperature at a high level in cold climates (Prins 1982). Although our study also identified lemming nests on cells with a dominant "moss-sedges tundra" vegetation, they were less strongly used than Dryas heath. The positive correlation with spot tundra (surface coverage between $31 \%$ and $60 \%$ ) suggests that a low vegetation cover does not affect lemming winter site selection at a certain level. However, habitat types with less than $10 \%$ vegetation cover are less likely to be inhabited by lemmings: Floodplain vegetation, which is also characterized by a low biomass and low plant species diversity, are being avoided by wintering lemmings, while we also found only low winter use of sand dunes habitat. 
Previous studies noted heterogeneity of microtopography as the most important factor determining both summer habitat (Morris et al. 2000) and winter habitat of lemmings (Duchesne et al. 2011; Schmidt et al. 2021). In line with these studies, slope had a positive effect in our model, and the increased usage of topographic features by wintering lemmings is an indirect effect of habitat configuration in the study region. Indeed, in contrast to the relatively flat plateaus and dunes, the steep slopes of gullies and terraces enhance the formation of deep snow drifts (Bilodeau et al. 2013a). Additionally, the hiemal threshold may be reached faster on wind-protected slopes than in less protected areas after the initial winter storms (Reid et al. 2012). Consequently, as the greatest winter snow accumulation attracts lemmings, this has been connected to a concentration of winter nests (Duchesne et al. 2011; Reid et al. 2012; Bilodeau et al. 2013). Probably because deeper snow will provide higher and more stable subnivean temperatures (Duchesne et al. 2011), thus reducing the physiological stress that lemmings undergo during winter (Bilodeau 2013b). The persistent pattern of snow-depth distribution mainly controlled the spatial distribution of vegetation in a snow modelling experiment in Zackenberg, Northeast Greenland (Pedersen et al. 2016). Here, Dryas heath occurred at significantly lower snow depth than observed for the remaining four other vegetation types (Pedersen et al. 2016). In addition, a snow fencing experiment on Herschel Island (Canadian Arctic) documented that the winter nest density intensified in areas with an artificially increased snow depth. After removing the fences, snow depth and winter nest density in the treatment area returned to pre-intervention conditions (Reid et al. 2012). The duration of the experiment on Herschel Island (one winter) would not have allowed for a shift in vegetation, emphasizing the dominant role of snow conditions in habitat use of lemmings. Winter nest site counts significantly dropped with higher elevations in our study. Here, lower snow accumulation due to greater exposition to wind and lower vegetation cover most likely forbid the establishment of amenable conditions necessary for survival of lemming in winter. However, we also add that the scale of our primal study cells complicates to determine which of the preceding factors may be of greater importance.

We found no evidence that nest counts are connected to different habitat features in years with high and low lemming abundances. Our results however indicate that, by using a wide array of different and abundant vegetation types, lemmings find enough winter nesting sites that are able to support even high lemming populations in peak years. Similarly, the study area provides an abundance of geomorphologic features providing thick snow covers needed for thermal insulation and protection of predators. Lemming populations, including D. groenlandicus on Traill Island, are assumed to be top-down controlled by specialist predators such as the ermine (Gilg et al. 2003; Sittler 1995). However, the ongoing warming of the Arctic and coupled shifts in habitat quantity and quality, along with changes in snow quality, are considered to be the prime factors to explain crash of lemming cycles and reduced overall population numbers (Gilg et al. 2009; Post et al. 2009). While the study region of Northeast Greenland has experienced only moderate shifts in vegetation cover (Schmidt et al. 2012a), recent weather extremes (Schmidt et al. 2019) suggest that alterations in snow regime could strongly impact lemming winter habitat use in the future.

\section{Conclusion}

The results of this study highlight the importance of both vegetation and topographical features as determinants of the spatial distribution of wintering lemming populations. As warming in the Arctic proceeds, lemmings will be confronted with significant changes in quality and quantity of their (still) abundant winter nesting sites. Shifts in vegetation, rain-on-snow events during autumn, and melt-freeze events in spring may alter the quality 
of these habitats. Consequently, a decrease in survival of lemmings in winter could be responsible for the recent distortions of population dynamics (Domine et al. 2018), which could potentially affect the whole tundra ecosystem (Gilg et al. 2019). Although lemmings do not decline on a global scale, regional disruptions may be the result of large geographical variability in climate, snow physical properties, and community composition across the Arctic (Ehrich et al. 2020). Future studies should aim to further investigate the relation of snow properties and lemming winter habitats. This could be done by applying highresolution local snow models to look at dynamic (snow) versus rather slowly changing (vegetation) environmental parameters. This would allow us to understand where lemmings would be more likely to persist with climate changes and finally to assess broader impacts on the structure and functioning of polar ecosystems.

\section{Acknowledgements}

As in any project of the magnitude of this long-term effort, many people helped in ways far too numerous to detail. Permission to undertake the study was granted by the Greenland Home Rule who also provided the yearly permits to get access to the National Park. Special thanks are due to the Groupe de Recherche en Ecologie Arctique (France) and the University of Freiburg (Germany) for staff and funding support as well as for providing research facilities. The members of the Danish Sledge Patrols Sirius (Joint Arctic Command) as well as the Norlandair Pilots helped us with logistics in the field. We also thank Dirk von Suchodoletz for his advice in setting up a cloud-based computing node and the state of Baden-Württemberg through bwCloud (https://www.bw-cloud.org/en/). Last, we thank Sandra Hamel for her advice in the statistical analyses.

\section{Competing interests statement}

The authors declare that there are no competing interests associated with this work.

\section{Funding statement}

This study was funded by the foundation "Menschen für Eisbären" along with private donors and sponsors of the "Karupelv Valley Project". The article processing charge was funded by the Baden-Wuerttemberg Ministry of Science, Research and Art and the University of Freiburg in the funding programme Open Access Publishing.

\section{Contributors' statement}

Xaver von Beckerath: conceptualization (lead); data curation (lead); formal analysis (equal); investigation (lead); methodology (lead); writing - original draft (lead); writing review and editing (lead). Gita Benadi: formal analysis (equal); writing - review and editing (supporting). Olivier Gilg: formal analysis (supporting); writing - review and editing (supporting). Benoît Sittler: funding acquisition (lead); conceptualization (supporting); writing - review and editing (supporting). Glenn Yannic: formal analysis (supporting); writing review and editing (supporting). Alexandra-Maria Klein: writing - review and editing (supporting). Bernhard Eitzinger: formal analysis (supporting); writing - review and editing (supporting).

\section{Data availability statement}

Lemming nests counts collected in the field, along with topographic data and vegetation data, is deposited in figshare (10.6084/m9.figshare.14892648). 


\section{References}

Ale, S.B., Morris, D.W., Dupuch, A., and Moore, D.E. 2011. Habitat selection and the scale of ghostly coexistence among Arctic rodents. Oikos, 120(8): 1191-1200. doi: 10.1111/j.1600-0706.2010.18933.X

Andreassen, P.N.S., Schmidt, N.M., Kapel, C.M.O., Christensen, M.U., Sittler, B., Gilg, O., et al. 2017. Gastrointestinal parasites of two populations of Arctic foxes (Vulpes lagopus) from north-east Greenland. Polar Research, 36: 13. doi: 10.1080/17518369.2017.1308667

Batzli, G., White, R., MacLean, S., Pitelka, F., and Collier, B. 1980. The herbivore-based trophic system. An arctic ecosystem: the coastal tundra at Barrow, Alaska Dowden. Hutchinson \& Ross, Stroudsburg PA.

Batzli, G., Pitelka, F., and Cameron, G. 1983. Habitat use by lemmings near Barrow, Alaska. Holarctic Ecol. 6(3): 255-262.

Berg, T. 2003. The collared lemming (Dicrostonyx groenlandicus) in Greenland: Population dynamics and habitat selection in relation to food quality. University of Copenhagen, Department of Population Ecology, Zoological Institute, Faculty of Science, Copenhagen.

Bergman, C., and Krebs, C. 1993. Diet overlap of collared lemmings and tundra voles at Pearce-Point, NorthwestTerritories. Can. J. Zool.-Rev. Canadienne De Zoologie, 71(9): 1703-1709. doi: 10.1139/z93-241.

Bilodeau, F., Reid, D.G., Gauthier, G., Krebs, C.J., Berteaux, D., and Kenney, A.J. 2013. Demographic response of tundra small mammals to a snow fencing experiment. Oikos, 122(8): 1167-1176. doi: 10.1111/j.1600-0706.2012.00220.x.

Bilodeau, F., Gauthier, G., and Berteaux, D. 2013a. Effect of snow cover on the vulnerability of lemmings to mammalian predators in the Canadian Arctic. Journal of Mammal. 94(4): 813-819. doi: 10.1644/12-MAMM-A-260.1.

Bilodeau, F., Gauthier, G., and Berteaux, D. 2013b. The effect of snow cover on lemming population cycles in the Canadian High Arctic. Oecologia, 172(4): 1007-1016. doi: 10.1007/s00442-012-2549-8.

Brooks, M.E., Kristensen, K., Benthem, K.J., van, Magnusson, A., Berg, C.W., Nielsen, A., et al. 2017. glmmTMB Balances Speed and Flexibility Among Packages for Zero-inflated Generalized Linear Mixed Modeling. R J. 9(2): 378-400. doi: 10.32614/RJ-2017-066.

Copernicus Sentinel data. 2017. For Sentinel data. Tile: S2A_tile_20170731_26XNF_0.

Domine, F., Gauthier, G., Vionnet, V., Fauteux, D., Dumont, M., and Barrere, M. 2018. Snow physical properties may be a significant determinant of lemming population dynamics in the high Arctic. Arctic Sci. 4(4): 813-826. doi: 10.1139/as-2018-0008.

Duchesne, D., Gauthier, G., and Berteaux, D. 2011. Habitat selection, reproduction and predation of wintering lemmings in the Arctic. Oecologia, 167(4): 967-980. doi: 10.1007/s00442-011-2045-6. PMID: 21701915.

Ehrich, D., Schmidt, N.M., Gauthier, G., Alisauskas, R., Angerbjorn, A., Clark, K., et al. 2020. Documenting lemming population change in the Arctic: Can we detect trends? Ambio, 49(3): 786-800. doi: 10.1007/s13280-019-01198-7. PMID: 31332767.

Fauteux, D., Gauthier, G., and Berteaux, D. 2015. Seasonal demography of a cyclic lemming population in the Canadian Arctic. J. Anim. Ecol. 84(5): 1412-1422. doi: 10.1111/1365-2656.12385. PMID: 25939755.

Fauteux, D., Gauthier, G., and Berteaux, D. 2016. Top-down limitation of lemmings revealed by experimental reduction of predators. Ecol. 97(11): 3231-3241. doi: 10.1002/ecy.1570.

Fauteux, D., Gauthier, G., Mazerolle, M.J., Coallier, N., Bêty, J., and Berteaux, D. 2018. Evaluation of invasive and non-invasive methods to monitor rodent abundance in the Arctic. Ecosphere, 9(2): e02124. doi: 10.1002/ecs2.2124.

Gilg, O., Hanski, I., and Sittler, B. 2003. Cyclic dynamics in a simple vertebrate predator-prey community. Science, 302(5646): 866-868. doi: 10.1126/science.1087509. PMID: 14593179.

Gilg, O., Sittler, B., Sabard, B., Hurstel, A., Sane, R., Delattre, P., and Hanski, L. 2006. Functional and numerical responses of four lemming predators in high arctic Greenland. Oikos, 113(2), 193-216. doi: 10.1111/j.2006.00301299.14125.X.

Gilg, O., Sittler, B., and Hanski, I. 2009. Climate change and cyclic predator-prey population dynamics in the high Arctic. Global Change Biol. 15(11): 2634-2652. doi: 10.1111/j.1365-2486.2009.01927.x.

Gilg, O., Bollache, L., Afonso, E., Yannic, G., Schmidt, N.M., Hansen, L.H., et al. 2019. Are gastrointestinal parasites associated with the cyclic population dynamics of their arctic lemming hosts? Inter. J. Parasitol.-Parasites Wild. 10: 6-12. doi: 10.1016/j.ijppaw.2019.06.011.

Gruyer, N., Gauthier, G., and Berteaux, D. 2008. Cyclic dynamics of sympatric lemming populations on Bylot Island, Nunavut, Canada. Can. J. Zool. 86(8): 910-917. doi: 10.1139/Z08-059.

Hall, L.S., Krausman, P.R., and Morrison, M.L. 1997. The Habitat Concept and a Plea for Standard Terminology. Wildlife Society Bulletin (1973-2006), 25(1): 173-182.

Hansen, B.U., Sigsgaard, C., Rasmussen, L., Cappelen, J., Hinkler, J., Mernild, S.H., et al. 2008. Present-Day Climate at Zackenberg. In Adv. Ecol. Res. 40: 111-149. Academic Press. doi: 10.1016/S0065-2504(07)00006-2.

Hartig, F. 2017. DHARMa: Residual Diagnostics for Hierarchical (Multi-Level/Mixed) Regression Models. R package version 0.1.5. [Online]. Available from https://CRAN.R-project.org/package=DHARMa.

Ims, R.A., and Fuglei, E. 2005. Trophic interaction cycles in tundra ecosystems and the impact of climate change. Bioscience, 55(4): 311-322. doi: 10.1641/0006-3568(2005)055[0311:TICITE]2.0.CO;2.

Ims, R.A., Henden, J.-A., and Killengreen, S.T. 2008. Collapsing population cycles. Trend Ecol. Evol. 23(2): 79-86. doi: 10.1016/j.tree.2007.10.010.

Ims, R.A., Yoccoz, N.G., and Killengreen, S.T. 2011. Determinants of lemming outbreaks. Proc. Natl. Acad. Sci. USA. 108(5): 1970-1974. doi: 10.1073/pnas.1012714108.

Kausrud, K.L., Mysterud, A., Steen, H., Vik, J.O., Ostbye, E., Cazelles, B., et al. 2008. Linking climate change to lemming cycles. Nature, 456(7218): 93-U3. doi: 10.1038/nature07442. PMID: 18987742. 
Klein, D., and Bay, C. 1994. Resource partitioning by mammalian herbivores in the high arctic. Oecologia, 97(4): 439-450. doi: 10.1007/BF00325880 PMID: 28313731.

Morris, D.W., Davidson, D.L., and Krebs, C.J. 2000. Measuring the ghost of competition: Insights from densitydependent habitat selection on the co-existence and dynamics of lemmings. Evol. Ecol. Res. 2(1): 41-67.

Morris, D.W., Moore, D.E., Ale, S.B., and Dupuch, A. 2011. Forecasting ecological and evolutionary strategies to global change: an example from habitat selection by lemmings. Glob. Change Biol. 17(3): 1266-1276. doi: 10.1111/ j.1365-2486.2010.02305.x.

Patterson, T., and Vaughn Kelso, N. 12 May 2018. Natural Earth Version 4.10. 1:10m Physical Vectors - Coastline. Available from https://www.naturalearthdata.com/downloads/10m-physical-vectors/10m-coastline/ [27 March 2020].

Pedersen, S.H., Tamstorf, M.P., Abermann, J., Westergaard-Nielsen, A., Lund, M., Skov, K., et al. 2016. Spatiotemporal Characteristics of Seasonal Snow Cover in Northeast Greenland from in Situ Observations. Arctic, Antarctic, and Alpine Research, 48(4): 653-671. doi: 10.1657|AAAR0016-028.

Porter, C., Morin, P., Howat, I., Noh, M.-J., Bates, B., Peterman, K., et al. 2018. ArcticDEM Release 5. Tile: 23_47_2_1_5m_v2.0_reg_dem [Data set]. Harvard Dataverse. doi: 10.7910/DVN/OHHUKH.

Pörtner, H.-O., Roberts, D.C., Masson-Delmotte, V., Zhai, P., Tignor, M., Poloczanska, E., et al. 2019. IPCC Special Report on the Ocean and Cryosphere in a Changing Climate. IPCC. Available from https://www.ipcc.ch/srocc/ download-report/.

Post, E., Forchhammer, M.C., Bret-Harte, M.S., Callaghan, T.V., Christensen, T.R., Elberling, B., et al. 2009. Ecological Dynamics Across the Arctic Associated with Recent Climate Change. Science, 325(5946): 1355-1358. doi: 10.1126/science.1173113. PMID: 19745143.

Predavec, M., and Krebs, C.J. 2000. Microhabitat utilisation, home ranges, and movement patterns of the collared lemming (Dicrostonyx groenlandicus) in the central Canadian Arctic. Can. J. Zool. 78(11): 1885-1890. doi: 10.1139/cjz78-11-1885

Prins, H.H.Th. 1982. Why Are Mosses Eaten in Cold Environments Only? Oikos, 38(3): 374-380. doi: 10.2307/3544680.

R Core Team. 2020. R: A Language and Environment for Statistical Computing. R Foundation for Statistical Computing, Vienna, Austria Available from https://www.R-project.org/.

Rau, F. July 1995. Geoökologische und hydrologische Untersuchungen in einem hochaktischen Tundrenökosystem auf Traill Ø, Nordost-Grönland. Unpublished diploma thesis. Albert Ludwig Universität Freiburg, Germany. Albert-Ludwigs-University Freiburg, Freiburg im Breisgau.

Reid, D.G., and Krebs, C.J. 1996. Limitations to collared lemming population growth in winter. Can. J. Zool. 74(7): 1284-1291. doi: 10.1139/z96-143.

Reid, D.G., Bilodeau, F., Krebs, C.J., Gauthier, G., Kenney, A.J., Gilbert, B.S., et al. 2012. Lemming winter habitat choice: a snow-fencing experiment. Oecologia, 168(4): 935-946. doi: 10.1007/s00442-011-2167-x. PMID: 22042523.

Rodgers, A., and Lewis, M. 1985. Diet selection in Arctic lemmings (Lemmus sibericus and Dicrostonyx groenlandicus): food preferences. Can. J. Zool. 63(5): 1161-1173. doi: 10.1139/z85-174.

Rodgers, A., and Lewis, M. 1986. Diet selection in Arctic lemmings (Lemmus sibiricus and Dicrostonyx groenlandicus): demography, home range, and habitat use. Can. J. Zool. 64(12): 2717-2727. doi: 10.1139/z86-396.

Schmidt, K.D., Michelsen, A., and Bay, C. 2012a. High Arctic plant community responses to a decade of ambient warming. Biodiversity, 13: 191-199. doi: 10.1080/14888386.2012.712093.

Schmidt, I.R.A., Hoye, T.T., Gilg, O., Hansen, L.H., Hansen, J., et al. 2012b. Response of an arctic predator guild to collapsing lemming cycles. Proce. Royal Soc. B-Biol. Sci. 279(1746): 4417-4422. doi: 10.1098/rspb.2012.1490.

Schmidt, N.M. 2000. Spatiotemporal distribution and habitat use of the collared lemming, Dicrostonyx groenlandicus Traill, in high arctic Northeast Greenland. University of Aarhus, Aarhus.

Schmidt, N.M., Reneerkens, J., Christensen, J.H., Olesen, M., and Roslin, T. 2019. An ecosystem-wide reproductive failure with more snow in the Arctic. PLoS Biol. 17(10): e3000392. doi: 10.1371/journal.pbio.3000392

Schmidt, N.M., van Beest, F.M., Dupuch, A., Hansen, L.H., Desforges, J.-P., and Morris, D.W. 2021. Long-term patterns in winter habitat selection, breeding and predation in a density-fluctuating, high Arctic lemming population. Oecologia, 195(4): 927-935. doi: 10.1007/s00442-021-04882-2 PMID: 33609167.

Sittler, B. 1995. Response of stoats (Mustela erminea) to a fluctuating lemming (Dicrostonyx groenlandicus) population in North-East Greenland - Preliminary results from a long-term study. Ann. Zool. Fennici, 32(1): 79-92.

Sittler, B., Gilg, O., and Berg, T.B. 2000. Low abundance of king elder nests during low lemming years in northeast Greenland. Arctic, 53(1): 53-60.

Soininen, E.M., Gauthier, G., Bilodeau, F., Berteaux, D., Gielly, L., Taberlet, P., et al. 2015. Highly overlapping winter diet in two sympatric lemming species revealed by DNA metabarcoding. PLoS ONE, 10(1): e0115335. doi: 10.1371/ journal.pone.0115335. PMID: 25635852.

Therrien, J.F., Gauthier, G., Korpimäki, E., and Bêty, J. 2014. Predation pressure by avian predators suggests summer limitation of small-mammal populations in the Canadian Arctic. Ecology, 95(1): 56-67. PMID: 24649646.

Viereck, L.A., and Little, E.L. 2007. Alaska Trees and Shrubs 2nd ed. University of Alaska Press, Fairbanks, AK.

Walker, D.A., Raynolds, M.K., Daniëls, F.J.A., Einarsson, E., Elvebakk, A., Gould, W.A., et al. 2005. The Circumpolar Arctic vegetation map. J. Veg. Sci. 16(3): 267-282. doi: 10.1111/j.1654-1103.2005.tb02365.x.

Zuur, A.F., Ieno, E.N., and Elphick, C.S. 2010. A protocol for data exploration to avoid common statistical problems. Meth. Ecol. Evol. 1(1): 3-14. doi: 10.1111/j.2041-210X.2009.00001.x. 